\title{
Awareness and Knowledge Regarding Soil Testing and Utility Perception of Soil Health Card
}

\author{
G.G. Patel, Y.C. Lakum, Aakash Mishra* and J.H. Bhatt
}

Krishi Vigyan Kendra, Anand Agricultural University, Devataj (Sojitra), Anand, Gujarat-387 240, India

*Corresponding author

\section{A B S T R A C T}

\section{Keywords}

Awareness,

Knowledge,

Perception, Soil

health cards and

Soil testing.

Article Info

Accepted:

04 September 2017

Available Online:

10 October 2017
The present investigation was undertaken in Petlad taluka of Anand district in middle Gujarat region. The random sampling of one hundred farmers from Petlad taluka was done based on number of respondent who had soil health cards. The result revealed that 52 per cent respondent belonged high to very high category with respect to knowledge of soil testing and use of soil health cards for advance farming. These farmers adopted the technology to balance the dose of fertilizers for sustaining soil health. This half of the majority found the technology beneficial for sustaining soil health, lowering the input cost and improving the farm production.

\section{Introduction}

Soil is one of the elements required for farming as it provides nutrients to the plant. Healthy soil contain all the elements for growth and development of crop or the soil deprived from one or more nutrient either reduce the production or degraded quality of crops. Therefore, proportion and quantity of macro and micro nutrients altogether refer to the soil health. As far as agriculture production is concerned, soil health play vital role in ensuring sustainable production with optimizing the utilization of fertilizer and reducing its waste. Most of the farmers are using continuously larger quantities of chemical fertilizers to increase production without knowing the fertility status of the soils of their fields (Srivastava and Pandey, 1999).

Soil Testing is well recognized as a sound scientific tool to assess inherent power of soil to supply plant nutrients. The benefits of soil testing have been established through scientific research, extensive field demonstrations and on the basis of actual fertilizer use by the farmers on soil test based fertilizer use recommendations. Neufeld and Davison (2000) stated that soil testing is the only necessary and available tool for determining the amount of soil nutrients. Hence, to avoid deterioration of soil in long run and visualizing the importance of balance 
nutrient in crop production, government of Gujarat commenced soil health card programme.

The soil health card is a simple document, which contains useful data on soil based chemical analysis of the soil to describe soil health in term of its nutrient availability and its physical and chemical properties. Gujarat became the first state to launch soil health card programme for the farmer. Soil health card can be used to optimize the use of fertilizer in the integrated nutrient management (INM) system. The soil health card programme brings together the scientific community in the field of agriculture, the information repository of latest tool, techniques and cropping practices, the farmers and the Government for the economics upliftment of the people at large. Since, change in knowledge preceded acceptance and application of an innovation, it is therefore, always important to find out the factor responsible for positive or negative disposition associated with farmer toward the usefulness and application of soil health card programme. Hence, present study was undertaken to measure the knowledge of benefits of soil testing and utility perception of soil health card.

\section{Materials and Methods}

The present study was undertaken in Petlad taluka of Anand district in Gujarat. The district is consisted of total number of eight talukas. Out of all eight talukas, Petlad taluka was inquisitively selected looking to the number of respondent had soil health card. One hundred farmers were randomly selected from ten different villages of Petlad taluka. A comprehensive list of all the respondents having SHC was obtained from e-dhara office of the respective villages. Thus, ten respondents from each village were selected at random for the study. The questionnaire was prepared in Gujarati language with a view to study and collect data through personal interview of the selected respondents. The data were tabulated and analyzed with the objectives to assess the knowledge of soil testing technology and perception to use soil health cards for advance farming.

\section{Results and Discussion}

\section{Demographic characteristics based on family profile}

The demographic characters of respondent played an important role in the usefulness and application of soil testing and soil health card programme. Some of the following family profile variables were selected, analyzed and presented in table 1 . The result revealed that among the five characters of the family profile, size of family and occupation found to be the most influencing factors in utilizing the technology whereas age, land holding and annual income did not establish any relation with the adoption of the technology. These findings are consistent with the results found by Rajput and Chinchmalatpure (2016).

The study revealed that 50 per cent farmers had occupation in mixed form i.e. agriculture + live stock farming and rest of 41 per cent and 9 per cent involved in practicing agriculture and agriculture + Livestock + business, respectively. Among the group of respondents, around 56 per cent of the respondents belonged to the middle age group i.e. 36 to 50 years with having large family size ( 60 per cent). Around 45 per cent farmers had small land holding i.e. 1 to 2 hectare and nearly 70 per cent farmers earn between Rs. $5,00,01$ to $1,00,000 /$-. Factors such as age, farming experience, training received, socioeconomic status, cropping intensity, aspiration, economic motivation, innovativeness, source of information and 
agent credibility have been found to have positive and significant association with adoption (Rao and Rao, 1996).

\section{Demographic characteristics based on personal profile}

The demographic characters of the farmers personal profile is directly or indirectly related with the family profile and suggests the positive chances of adoption of the technology.

The result revealed that among the five characters of the personal profile, education and resources of farmers found to be the most influencing factors in utilizing the technology whereas farming experience, social participation and source of finance had lower extent of influence on adoption (Table 2). In personal characterization of all respondents, about 42 per cent farmers had secondary level of education i.e. $8^{\text {th }}$ to $10^{\text {th }}$ standard and only 18 per cent had higher secondary to graduate level education. In Petlad taluka nearly 65 per cent farmers had experience for more than 21 years in the field of agriculture without any social participation (61 per cent). The majority of the farmers (53 per cent) in the region considered Government sector or banks as a source to support their financial needs.

Adoption of any technologies due to personal profile like education, farming experience, social participations, source of finance and resources of farmer play a major role (Rai and Saharia, 2004).

Table.1 Demographic characteristics of the respondents according to family profile

\begin{tabular}{|c|c|c|c|c|}
\hline & & & & $\mathrm{n}=\mathbf{1 0 0}$ \\
\hline S. No. & Characteristic & Category & $\begin{array}{l}\text { Number of } \\
\text { Farmers }\end{array}$ & $\begin{array}{c}\% \\
\text { Distribution }\end{array}$ \\
\hline \multirow{3}{*}{1.} & \multirow{3}{*}{ Age } & Young (Up to 35 year) & 06 & 6.00 \\
\hline & & Middle (36 to 50 year) & 56 & 56.00 \\
\hline & & Old (Above 50 year) & 38 & 38.00 \\
\hline \multirow{4}{*}{2.} & \multirow{4}{*}{ Land holding } & Landless & 0 & 0.00 \\
\hline & & Marginal (Up to 1 ha.) & 42 & 42.00 \\
\hline & & Small (Above 1 to 2 ha.) & 45 & 45.00 \\
\hline & & Large (Above 2 ha.) & 13 & 13.00 \\
\hline \multirow{3}{*}{3.} & \multirow{3}{*}{ Annual income } & Low (Up to Rs.50,000) & 27 & 27.00 \\
\hline & & Medium (Rs.50,001 to Rs.1,00,000) & 70 & 70.00 \\
\hline & & High (> Rs.1,00,000) & 3 & 3.00 \\
\hline \multirow{2}{*}{4.} & \multirow{2}{*}{ Size of family } & Small (Up to 5 member) & 40 & 40.00 \\
\hline & & Large (> 5 member) & 60 & 60.00 \\
\hline \multirow{3}{*}{5.} & \multirow{3}{*}{ Occupation } & Only Agriculture & 41 & 41.00 \\
\hline & & $\begin{array}{l}\text { Agriculture with Live stock } \\
\text { Farming }\end{array}$ & 50 & 50.00 \\
\hline & & $\begin{array}{l}\text { Agriculture with Livestock farming } \\
\text { and Business/Service }\end{array}$ & 09 & 09.00 \\
\hline
\end{tabular}


Table.2 Demographic characteristics of the respondents according to personal profile

\begin{tabular}{|c|c|c|c|c|}
\hline & & & & $n=100$ \\
\hline S. No & Characteristic & Category & $\begin{array}{c}\text { Number of } \\
\text { Farmers }\end{array}$ & $\begin{array}{c}\% \\
\text { Distribution }\end{array}$ \\
\hline \multirow{5}{*}{1.} & \multirow{5}{*}{ Education } & Illiterate & 06 & 6.00 \\
\hline & & Primary ( 1 to $7^{\text {th }}$ Std $)$ & 34 & 34.00 \\
\hline & & Secondary $\left(8^{\text {th }}\right.$ to $\left.10^{\text {th }}\right)$ & 42 & 42.00 \\
\hline & & $\begin{array}{l}\text { Higher Secondary }\left(11^{\text {th }} \text { to }\right. \\
\left.12^{\mathrm{th}}\right)\end{array}$ & 04 & 4.00 \\
\hline & & Graduate and above & 14 & 14.00 \\
\hline \multirow{3}{*}{2.} & \multirow{3}{*}{$\begin{array}{l}\text { Farming } \\
\text { Experience }\end{array}$} & Low (1 to 10 years) & 07 & 07.00 \\
\hline & & Medium (11 to 20 years) & 28 & 28.00 \\
\hline & & High $(>21$ years $)$ & 65 & 65.00 \\
\hline \multirow{4}{*}{3.} & \multirow{4}{*}{$\begin{array}{l}\text { Social } \\
\text { participations }\end{array}$} & No participation & 61 & 61.00 \\
\hline & & Participation in 1 organization & 26 & 26.00 \\
\hline & & Participation in 2 organization & 12 & 12.00 \\
\hline & & $\begin{array}{l}\text { Participation in more than } 2 \\
\text { organization }\end{array}$ & 01 & 01.00 \\
\hline \multirow{4}{*}{4.} & \multirow{4}{*}{ Source of Finance } & No Finance & 09 & 09.00 \\
\hline & & Private Sector & 02 & 02.00 \\
\hline & & Govt. Sector/ Bank & 53 & 53.00 \\
\hline & & Co- operative Sector & 36 & 36.00 \\
\hline \multirow{3}{*}{5.} & \multirow{3}{*}{$\begin{array}{l}\text { Resources of } \\
\text { Farmer }\end{array}$} & Low $(0-25)$ & 62 & 62.00 \\
\hline & & Medium (26-50) & 35 & 35.00 \\
\hline & & High (above 50) & 03 & 03.00 \\
\hline
\end{tabular}

Table.3 Knowledge regarding benefits of soil testing and utility perception of soil health Card (SHC)

\begin{tabular}{|c|c|c|c|c|}
\hline & & & & $n=100$ \\
\hline S. No. & Characteristic & Category & $\begin{array}{c}\text { Number of } \\
\text { Farmers }\end{array}$ & $\begin{array}{c}\% \\
\text { Distribution }\end{array}$ \\
\hline \multirow{5}{*}{1.} & \multirow{5}{*}{$\begin{array}{l}\text { Knowledge regarding benefits of } \\
\text { Soil Testing }\end{array}$} & Very Low (0-20) & 14 & 14.00 \\
\hline & & Low $(21-40)$ & 18 & 18.00 \\
\hline & & Medium (41-60) & 16 & 16.00 \\
\hline & & High $(61-80)$ & 37 & 37.00 \\
\hline & & $\begin{array}{l}\text { Very High } \\
\text { (Above } 80)\end{array}$ & 15 & 15.00 \\
\hline \multirow{5}{*}{2.} & \multirow{5}{*}{$\begin{array}{l}\text { Knowledge regarding utility } \\
\text { perception about Soil Health Card }\end{array}$} & Very Low (0-20) & 14 & 14.00 \\
\hline & & Low $(21-40)$ & 18 & 18.00 \\
\hline & & Medium (41-60) & 16 & 16.00 \\
\hline & & High $(61-80)$ & 37 & 37.00 \\
\hline & & $\begin{array}{l}\text { Very High } \\
\text { (Above } 80)\end{array}$ & 15 & 15.00 \\
\hline
\end{tabular}




\section{Level of Knowledge}

Adoption of technology is the decision to make full use of a new idea as the best course of action available and involves a change in the orientation and behaviour of the farmer from the time he/she becomes aware of the technology to its adoption (Akubuilo et al., 1982). In the study knowledge about soil testing was analyzed with the help of some variables which are presented in table 3 . The data revealed that 52 per cent of the respondent had high to very high level of knowledge with respect to soil testing and perception to use soil health card in advance agriculture system. Knowledge regarding the benefit of soil testing was found most important for SHC programme. Agbamu's (1993) findings stated that farmers' knowledge of technology made contribution to its adoption. They found the technology satisfactory and important with respect to lower the input cost, benefit of soil testing and use of soil health card in their farming operation. Chowdary et al., (2016) also found that more than two-thirds (67 per cent) of the respondents had high level of satisfaction on SHC recommendations. These findings are consistent with the results found by Srivastava and Pandey (1999), Yadav et al., (2005), Pagaria (2011) and Patel and Chauhan (2012). To ensure the importance of the technology state government has always given their advisement in time interval to enhance balance and efficient use of fertilizers based on soil testing and soil health cards.

\section{Constraints in adoption of the technology}

It was found that around one third respondents reported very low to low adoption of the recommended technology in the Petlad taluka region. These respondents reported the hurdles while utilizing the technology which limited the extent of their adoption to this technology. These points are needed to be considered for the future study based on farmers reporting a) Understanding of soil testing is difficult b) Delay in getting the test reports on time c) Difficulty in following test based fertilizer recommendation d) No certainty in yield gain e) No proper and scientific guidance.

It can be concluded that majority of respondent from Petlad taluka are of middle age and literate. Majority of the respondent had medium to very high (68 per cent) level knowledge about benefits of soil testing and use of soil health card (SHC). Educational awareness and resource laboratory to test soil samples in nearby location found to be the most influential factor in adoption of the technology. Therefore, as per problem faced and suggested by the farmers more scientific and educational trainings and facilities are required to disseminate the technology at large. Extension worker can take their lead in this to overcome the barriers in adoption of the technology.

\section{Acknowledgement}

The authors wish to thank department of extension education, Anand Agricultural University for the support and encouragement during the investigation.

\section{References}

Agbamu, J. U., 1993. Analysis of Farmers' Characteristics associated with Adoption of Soil Management Innovations in Ikorodu Local Government Area of Lagos State. Nigeria Journal of Rural Extension and Development. 1(2 \& 3): 57-67.

Akubuilo, C. J. C., 1982. Adoption of innovation among farmers in Anambra state. Unpublished M.Sc. thesis Dept of Agric. Extension, University of Nigeria, Nsukka.

Chowdary, K., Raghavendra and Theodore, 
Ravi Kumar, 2016. Soil Health Card Adoption Behaviour among Beneficiaries of Bhoochetana Project in Andhra Pradesh. Journal of Extension Education. 28(1): 5588-5597.

Neufeld, J., Cramb, R., D. Catacutan, Z. Culasero-Arellano and K. Mariano, 2006. Farm-level impacts of land care in Lantapan. Working Paper, No. 5. Philippines- Australia: Land Care Project.

Pagaria, P., 2011. Knowledge and attitude of small and marginal farmers towards soil testing. Journal of Advances in Developmental Research. 2(2): 171173.

Patel, J. K., and Chauhan, N. B. 2012. Attitude of farmers towards soil health card (SHC) programme. Asian Journal of Soil Science. 7(1): 114-116.

Rai, M. N., and Saharia, K. K. 2004. Sociopersonal and economic profile of the dairy farmer in the Kamrup district of Assam, Rural India. 67(4): 61-64.

Rajput, H. D., and Chinchmalatpure, Umesh R. 2016. Knowledge and Adoption of Bt Cotton Cultivation Practices. Indian Journal of Extension Education. 52(1\&2):121-123.

Rao, P. P., and Rao, V. G. K. 1996. Adoption of rice production technology by the tribal farmers. Journal of research and ANGRAU. 24(1-2): 21-25.

Srivastava, Y. C., and Pandey, A. P. 1999. Knowledge and attitude of small and marginal farmers towards soil testing. Agricultural Extension Review. 11(6): 3-6.

Yadav, S. P. V., Raman, S.R. and Kumar, R. 2005. Knowledge and attitude farmers towards soil testing practices. Indian Research Journal of Extension Education. 6: 1-3.

\section{How to cite this article:}

Patel, G.G., Y.C. Lakum, Aakash Mishra and Bhatt, J.H. 2017. Awareness and Knowledge Regarding Soil Testing and Utility Perception of Soil Health Card. Int.J.Curr.Microbiol.App.Sci. 6(10): 329-334. doi: https://doi.org/10.20546/ijcmas.2017.610.040 